\title{
New Promising Rice Genotypes of SP87-1-1-2 and SP73-3-1- 7 Adaptive to Lowland and Medium Land
}

\author{
DOI: $10.18196 /$ pt.2020.110.21-32
}

\author{
Fitri Utami Hasan ${ }^{1}$, Santika Sari ${ }^{2}$, Anas $^{2}$, Nono Carsono ${ }^{2 *}$ \\ ${ }^{1}$ Master Program of Agronomy, Plant Breeding Concentration, Faculty of Agriculture, Universitas Padjadjaran, \\ Jatinangor, Sumedang 45363, Indonesia \\ ${ }^{2}$ Plant Analysis and Biotechnology Laboratory, Faculty of Agriculture, Universitas Padjadjaran, \\ Jatinangor, Sumedang 45363, Indonesia \\ *Corresponding author, email: n.carsono@unpad.ac.id
}

\begin{abstract}
High yield potential (more than 8 ton ha-17), resistant to pest and disease, adaptive to specific or broad environment and good palatability are among rice traits preferred by farmers and consumers. In order to develop such superior rice, yield testing at different agro-climates for some promising lines bred is necessary. This study aimed to examine selected rice genotypes in two different environments, namely Indramayu (9m asl) and Jatinangor (752m asl) and to obtain environment factors affecting the plant trait variation. The experiment was conducted during dry season with fifteen $F_{5}$ genotypes, arranged in an augmented design. Based on Least Significant Increase (LSI), genotypes showing better performance than checks were SP87-1-1 on number of productive tillers and total grain weight, SP73-3-1 on panicle length, total grain weight, and weight of 1000 grains. Meanwhile, SP46-4-1 and SP87-4-1 showed better number of filled grains than checks in Indramayu. There was no genotype performing higher number of empty grains than that of the checks. Based on the Principle Component Analysis (PCA), altitude contributed to high variation of plant traits. SP87-1-1 and SP73-3-1 are recommended to be grown in medium and lowland ecosystem because they have high productivity in both environments.
\end{abstract}

Keywords: Augmented; Biplot; PCA; Yield trial

\section{ABSTRAK}

Padi berproduktivitas tinggi (>8 ton ha-1), tahan hama dan penyakit utama, adaptif untuk lingkungan spesifik atau luas, serta memiliki mutu tanak baik merupakan karakter yang diharapkan oleh petani dan konsumen. Guna merakit genotipe superior tersebut, dibutuhkan pengujian galur harapan yang telah dimuliakan sebelumnya pada lokasi dengan kondisi agroklimat yang berbeda. Penelitian bertujuan memperoleh daya hasil genotipe padi pada dua lingkungan yaitu Indramayu (9m dpl) dan Jatinangor (752m dpl) serta memperoleh faktor lingkungan yang memberikan kontribusi besar terhadap variasi karakter padi. Percobaan menggunakan padi $F_{5}$ dari 15 genotipe terseleksi menggunakan rancangan augmented. Berdasarkan LSI (Least Significant Increase) genotipe yang memiliki nilai lebih baik dari cek yaitu SP87-1-1 untuk karakter jumlah anakan produktif dan berat total; SP73-3-1 untuk karakter panjang malai, bobot gabah isi per tanaman, dan bobot 1000 butir. Pada jumlah gabah isi tidak terdapat genotipe yang lebih baik ceknya. SP46-4-1, dan SP87-4-1 menunjukkan hasil lebih baik dibanding cek pada jumlah gabah isi di Indramayu. Pada jumlah gabah hampa hampir seluruh genotipe tidak lebih baik dari cek. Berdasarkan PCA (Principle Component Analysis), ketinggian tempat memberikan kontribusi terbesar terhadap variasi karakter padi. SP87-1 - 1 dan SP73-3-1 direkomendasikan untuk ditanam pada dataran medium dan rendah karena memiliki produktivitas tinggi pada kedua lingkungan tersebut.

Kata Kunci: Augmented; Biplot; PCA; Komponen hasil

\section{INTRODUCTION}

It is estimated that world human population will improving rice productivity and expanding plantreach 8 billion by 2030. It is therefore rice produc- ing area. To improve rice productivity, innovation tion has to be improved by $50 \%$ in order to fulfil in genetic improvement of rice should be developed the demand (Khush and Brar, 2002). Indonesia, to create new rice plant types with high yielding, as the third largest rice consumer country, has to prepare for this challenge. According to West Java Central Agency on Statistics (2015), within one decade, rice production in West Java Province is much fluctuated, even decreasing from 12.083 .162 ton in 2013 to 11.644 .899 ton in 2014, then it continued to decline to 11.373 .144 ton in 2015. The decline in rice production should be overcome by resistant to biotic and abiotic stresses, and high grain quality. Meanwhile, expanding planting area for rice cultivation can be done by opening new land and controlling the conversion of agricultural land to non-agricultural use (Syuriani et al., 2013). Expanding planting area can be an option for facing the emerging issues, such as the increasing human population and climate change. 
In addition, high yield and resistance to major pest and disease are main focus of rice breeding as strategic commodity for the development throughout Indonesia with diverse agro-climatic conditions. In order to improve rice productivity, the breeding progress with yield component as a main target (Akinwale et al., 2011) can be seen through yield trial. Yield testing for promising rice lines on various locations with different agroclimatic condition is highly needed since there is a genotype by environment interaction, especially for quantitative traits.

Environment factors contribute to genotype performance. One of the responses of rice plants to the environment is shown by the level of adaptability. Plants are classified to be adaptive if they are able to show good yield on various environmental conditions (Annicchiarico, 2002). Some rice cultivars have been known to have different adaptability in specific or broad location. For example, some rice lines as found by Dianawati and Noviana (2015) are adaptive to low land ecosystem. Meanwhile, Caredek Putih and Caredek Merah, local varieties grown in West Sumatera (Syarif and Zen, 2012), are adaptive to high altitude. Other cultivar such as IR64 is well known as high-yielding mega-variety that has a broad adaptation (Mackill and Kush, 2018). These data suggest that genetic composition of rice, especially genes that controlling adaptation ability, play significant role in determining adaptability. Information regarding on environmental factors of two research locations are interesting to be elaborated. In addition, two diverse locations will give more information regarding to the environmental factors mostly contributing to the rice variations observed that will be analyzed by PCA (Principal Component Analysis; Pearson, 1901).

Yield trial has been done previously for some rice genotypes, yet it could not provide information on the specific environmental factors that contrib- ute to the variation of rice traits. In this experiment, specific environment factors that contribute to the variation were comprehensively analyzed, making it different from some experiments that have been done (Uzzaman et al., 2015, Barma et al., 2018, Abebrese et al., 2019). Therefore, the objectives of the experiment were to obtain yield potential of promising improved rice lines in two diverse locations and to determine any specific environments that contribute significantly to the variation of observed rice traits.

\section{MATERIALS AND METHODS}

\section{Experiment Location}

The experiment was carried out from June to November 2016 in two sites with different growing condition, which were Karangampel (Indramayu) and Jatinangor (Sumedang). Both locations were chosen based on the difference in altitude and agroclimate. The description of both sites is provided in the Background. Indramayu has an altitude of $9 \mathrm{~m}$ above sea level (asl), coastal area, climatic type tropical warm with a temperature of $22.9-30^{\circ} \mathrm{C}$, humidity of $70-90 \%$, latitude of -6.49465 and longitude of 108.4244 , climatic type D according to Schmidt and Ferguson, and is one of national rice production centers. Meanwhile, Jatinangor has an altitude of $\pm 753 \mathrm{~m}$ asl with latitude of -6.91752 and longitude of 107.7704 , and climatic type C according to Schmidt and Ferguson (Kementerian Pertanian, 2015b).

\section{Plant Materials}

Seeds of 15 new promising rice lines (F5) derived from previous molecular and phenotypic selection and eight check cultivars were used. The checks were Pandanwangi, Sintanur, IR-64, PTB-33 (parents) and some widely grown cultivars, i.e. IR42, Inpari-13, Ciherang, and Kebo (local variety). 


\section{Experimental Design and Data Analysis}

The experiment was arranged in augmented design that is suitable with limited number of seeds available. Sharma (2006) pointed out that augmented design applied for inappropriate land condition and number of genetic materials tested. Variables measured were yield and its component, including number of productive tillers, panicle length, number of filled graons, number of empty grains, weight of 1000 gains, and total grain weight per plant. Environmental elements observed were latitude (LT), longitude (LG), altitude (HG), maximum temperature (TMAX), minimum temperature (TMIN), average temperature (TAVG), rainfall $(\mathrm{RN})$, relative humidity $(\mathrm{RH})$, photoperiod (SUN), maximum wind speed (MAXWD), average air pressure (AVGUST), and average wind speed (AVGWD). Data normality was tested by using Kolmogorov-Smirnov Z, while Bartlett's test was used for homogeneity of variance and then continued to combined analysis of variances. Comparison of agronomic performance and yield of new promising genotypes with those of the checks on the two sites was performed by LSI (Least Significant Increase). Estimation of environmental contribution to the variation of rice traits was conducted by PCA (Principal Component Analysis).

\section{RESULTS AND DISCUSSION}

Preliminary yield testing for some crops has been practiced by breeders since some years ago in order to evaluate promising genotypes under different locations or environments. This study presented preliminary yield trial of 15 new promising rice lines in two locations. A combined analysis of variance for yield and yield component traits to obtain genotype by environment interaction was performed. Petersen (1994) mentioned that genotype by environment interaction illustrated whether the genotypes tested were uniform in dif- ferent environments. Genotypes that performed constant superior traits in all locations could be developed into widely adapted varieties, and then they could be released (Ganefianti et al., 2009). In this experiment, normality test found that the data were normally distributed, and the variance was homogenous, thus the data were valid for a combined ANOVA as presented in Table 1.

Table 1. A combined ANOVA analysis for yield and yield component on two locations

\begin{tabular}{lllll}
\hline No. & Traits & $\begin{array}{c}\mathrm{CV} \\
(\%)\end{array}$ & $\begin{array}{c}\text { Mean } \\
\text { Square GXE }\end{array}$ & $\begin{array}{c}\mathrm{F} \text { value } \\
\mathrm{GXE}\end{array}$ \\
\hline 1. & Number of productive tillers & 11 & 30.52 & $8.74^{*}$ \\
2. & Length of panicle & 4 & 12.97 & $14.41^{*}$ \\
3. & Number of filled grains & 3 & 47584.49 & $23.15^{*}$ \\
4. & Number of empty grains & 9 & 9053.87 & $3.56^{*}$ \\
5. & Weight of 1000 grains & 2 & 17.94 & $81.55^{*}$ \\
6. & Total grain weight per plant & 1 & 110.01 & $250.02^{*}$ \\
\hline
\end{tabular}

Remarks: * significantly different at $\mathrm{p}<0.05$ based on combined ANOVA; $\mathrm{CV}=$ Coefficient of Variation; GxE = Genotype by Environment Interaction.

Referring to Table 1, it was found that there was genotype by environment interaction effect on six traits in both locations. The genotypes tested differed in their performance in both locations. It also indicated that the performance of traits was affected by genotype by environment interaction. Fehr (1987) stated that the influence of the environment on genotype by environment interaction was often related to location and season factors. Variation on environmental factors such as temperature, relative humidity, rain fall, photoperiod, light intensity, soil fertility, and other factors could contribute to the interaction phenomenon affecting rice yield. Significant performance of yield and yield component traits exhibited the variability of rice traits in both planting locations.

Based on Table 1, the range of the Cofficient of Variation (CV) was around 1-11\%. It implies that the data are good since the CV value is less than $20 \%$ as stated by Gasperz (2006), and the traits 
observed have a relatively high level of confidence. Assessing yield potential was one of the objectives The greater the $\mathrm{CV}$, the greater the significance of this experiment. Yield in rice was dominated by level of the study conducted. It also reveals that three traits, namely the number of tillers per plant, the data collection was valid and well conducted. number of filled grain, and grain weight (Xue et

\section{Yield potential of 15 Promising Rice Genotypes}

Improving yield potential of rice is an important objective for almost all rice researchers (Gravois and Helms, 1992). Rice genotypes as genetic material used in this experiment had reached F5 generation with unknown yield potential. Previous phenotypic and molecular selection for aromatic trait and resistance to brown plant hopper has been made. al., 2008). These three traits were already included in this experiment as main variables.

\section{Number of productive tillers and length of panicle}

The genotypes of rice grown in Indramayu showed good response on the number of productive tillers (Table 2). Three genotypes of SP87-30-1, SP87-4-1, and SP87-1-1 were better in the numTable 2. LSI test for number of productive tillers and length of panicle in Indramayu and (Jatinangor) Sumedang

\begin{tabular}{|c|c|c|c|c|c|c|c|c|c|}
\hline \multirow{3}{*}{ No. } & \multirow{3}{*}{ Genotype } & \multicolumn{4}{|c|}{ Number of productive tillers } & \multicolumn{4}{|c|}{ Length of panicle $(\mathrm{cm})$} \\
\hline & & \multicolumn{2}{|c|}{ Indramayu } & \multicolumn{2}{|c|}{ Jatinangor (Sumedang) } & \multicolumn{2}{|c|}{ Indramayu } & \multicolumn{2}{|c|}{ Jatinangor (Sumedang) } \\
\hline & & Value & Notation & Value & Notation & Value & Notation & Value & Notation \\
\hline 1. & IP158-5-1 & 18.07 & fh & 16.68 & bcfgh & 21.36 & & 21.65 & e \\
\hline 2. & PP48-3-1 & 15.43 & $f$ & 17.32 & bcfgh & 23.8 & bdfgh & 20.48 & \\
\hline 3. & SP101-3-1 & 17.43 & fh & 17.52 & bcfgh & 22.46 & $g h$ & 21.08 & e \\
\hline 4. & SP46-4-1 & 22.31 & adefgh & 22.83 & bcdefgh & 21.57 & & 19.57 & \\
\hline 5. & SP73-1-1 & 19.33 & dfgh & 22.08 & bcdefgh & 21.61 & & 22.95 & eh \\
\hline 6. & SP73-3-1 & 18.82 & fgh & 17.21 & bcfgh & 26.12 & abcdgh & 24.18 & e \\
\hline 7. & SP87-10-1 & 18.71 & fgh & 19.73 & bcdefgh & 19.89 & & 21.35 & e \\
\hline 8. & SP87-1-1 & 25.62 & abcdefgh & 23.08 & bcdefgh & 23.13 & fgh & 21.56 & e \\
\hline 9. & SP87-15-1 & 16.11 & fh & 12.9 & gh & 21.32 & & 22.02 & e \\
\hline 10. & SP87-24-1 & 15.96 & $f$ & 12.29 & $g h$ & 22.02 & & 22.79 & e \\
\hline 11. & SP87-25-1 & 19.24 & fgh & 15.29 & fgh & 21.14 & & 23.12 & e \\
\hline 12. & SP87-26-1 & 23.25 & adefgh & 12.74 & gh & 23.35 & efgh & 19.78 & \\
\hline 13. & SP87-27-1 & 23.15 & adefgh & 17.89 & bcfgh & 21.53 & & 28.03 & bcdefh \\
\hline 14. & SP87-30-1 & 26.56 & abcdefgh & 16.63 & bcfgh & 21.81 & & 20.63 & \\
\hline 15. & SP87-4-1 & 30.89 & abcdefgh & 13.64 & fgh & 22.41 & gh & 20.62 & \\
\hline 16. & PTB-33 (a) & 20.08 & & 23.32 & & 24.59 & & 28.11 & \\
\hline 17. & IR-42 (b) & 23.32 & & 15.65 & & 23.61 & & 24.28 & \\
\hline 18. & Kebo (c) & 23.65 & & 15.98 & & 24.11 & & 25.28 & \\
\hline 19. & Pandanwangi (d) & 19.32 & & 19.32 & & 23.28 & & 23.45 & \\
\hline 20. & IR-64 (e) & 20.09 & & 18.03 & & 27.24 & & 20.90 & \\
\hline 21. & Sintanur (f) & 12.92 & & 12.96 & & 22.97 & & 25.02 & \\
\hline 22. & Inpari-13 (g) & 18.61 & & 9.81 & & 22.23 & & 24.03 & \\
\hline 23. & Ciherang (h) & 11.98 & & 11.68 & & 22.41 & & 22.84 & \\
\hline
\end{tabular}

Remarks: LSI (Least Significant Increase) value for number of productive tillers $=0.647569$; panicle length= 0.275346; Alphabet $a, b, c, d, f, g, h$ means that that the tested genotype is significantly different compared to the checks listed as follow: $a=P T B-33, b=I R-42, c=K e b 0, d$ $=$ Pandanwangi, $e=I R-64, f=$ Sintanur, $g=$ Inpari, $h=$ Ciherang according to $L S I$ at $5 \%$. 
checks (PTB-33, IR-42, Kebo, Pandanwangi, IR-64, Sintanur, Inpari-13, Ciherang). Meanwhile, in Jatinangor, there were no genotypes performing better than the seven checks (IR-42, Kebo, Pandanwangi, IR-64, Sintanur, Inpari-13, Ciherang), except four genotypes of SP46-4-1, SP73-1-1, SP87-10-1, and SP87-1-1. Number of productive tillers is important trait that contributes to rice yield. Tiller development in rice is affected by many factors, including organic materials in soils, planting distance, and weather conditions such as light intensity, temperature, and water supply (Yan et.al., 1998). According to LSI, the genotype of SP87-1-1 tended to be better than the checks in the two locations. Number of tillers is a quantitative trait inherited from the parents (Xiong, 1992). Number of productive tillers of PTB-33 was greater than that of Sintanur in both locations. However, the genotype of SP87-1-1, progeny of PTB-33 and Sintanur, had productive tillers that was much higher than their parents. It is likely that number of productive tillers from both parents is successfully inherited. Genetic composition in terms of allelic composition of SP87-1-1 is favorable in controlling number of productive tillers. This character will develop more optimally along with the decrease in the number of unproductive tillers. Sheehy et al. (2001) pointed out that one of the goals of rice breeding in the terms of agronomy in existing cultivars was to minimize the number of unproductive tillers. Unproductive tillers do not contribute to the increasing Leaf Area Index (LAI) and yield. An increase in the number of productive tillers can be optimized by increasing the organic matter, photoperiod, and irrigation (Yan et al., 1998).

Based on LSI (Table 2), SP73-3-1 had significantly longer panicle length than that of the six checks (PTB-33, IR-42, Kebo, Pandanwangi, Inpari-13, Ciherang). SP87-27-1 had significant longer panicle length with those of the checks (IR-42,
Kebo, Pandanwangi, IR-64, Sintanur, Ciherang). Panicle is composed by many spikelets and rachillae comprising peduncle and primary, secondary, and tertiary branches. Ando et al. (2008) argued that optimization of panicle balance with its components is needed to increase the number of spikelets directly determining the increase in rice yield. In general, high yielding variety from indica subspecies is tended to have many spikelets than japonica due to longer panicle and stem and higher number of primary and secondary stems. Genotypes used in the experiment are derived from hybridization of cultivars that belong to indica subspecies. Fifteen promising genotypes used in this experiment are predicted to have higher yield than japonica.

The yield of rice plants manifested by the total amount of grain harvested can be divided into two components, namely sink size (the potential capacity for maximum production of crop) and source size (the potential capacity to utilize the photosynthetic products). The source-sink relationship in plants affects the rate of crop yield that is influenced by environmental conditions (Smith et al., 2018). Genotype of SP73-3-1 had better tendency than some checks at in the two planting locations, but it could not exceed panicle length of both parents (Table 1).

Panicle length of the progenies, namely SP (Sintanur xPTB-33), IP (IR-64 x PTB-33), and PP (Pandan Wangi $x$ PTB-33), was not exceeding that of their parents, and this trait is a quantitative trait with low heritability (Mohamed et al., 1965). It is possible if the offsprings do not have traits like the parents nor the combination of the characters of the two parents because this character is difficult to inherit. Panicle development is affected by many environmental factors (Yan et al., 1998). Baker et al. (1992) found that the optimum temperature for rice cultivation was around $22-28^{\circ} \mathrm{C}$. The average temperature in Indramayu and Jatinangor planting 
were $32.5^{\circ} \mathrm{C}$ and $28.5^{\circ} \mathrm{C}$, respectively. The temperature in Indramayu is not in accordance with the optimum temperature criteria according to Baker et al. (1992). This lack of optimum temperature affected the panicle length in Indramayu, which was not better than in Jatinangor

\section{Number of filled and empty grains}

Filled grain is one of the characters that determine the rice yield. The data from LSI analysis showed an interesting phenomenon because of the contrast of the analysis results in Jatinangor (Table 3). Based on LSI analysis, there was no genotype performing higher number of filled grains compared to the checks in Jatinangor. Meanwhile, in Indramayu, there were nine genotypes that were better than several checks, and there was one genotype that was better than all checks (PTB-33, IR-42, Kebo, Pandanwangi, IR-64, Sintanur, Inpari-13, Ciherang), which was SP87-27-1.SP87-24-1 was the most superior genotypes among other genotypes grown in Indramayu because it had a lower number of empty grains than that of five checks (IR-42, IR-64, Sintanur, Inpari-13, and Ciherang) (Table 3). The genotype of IP158-5-1 became the most superior genotype in Jatinangor with lower

Table 3. LSI test for number of filled grains and number of empty grains of rice grown in Indramayu dan Jatinangor (Sumedang)

\begin{tabular}{|c|c|c|c|c|c|c|c|c|c|}
\hline \multirow{3}{*}{ No. } & \multirow{3}{*}{ Genotype } & \multicolumn{4}{|c|}{ Number of filled grains } & \multicolumn{4}{|c|}{ Number of empty grains } \\
\hline & & \multicolumn{2}{|c|}{ Indramayu } & \multicolumn{2}{|c|}{ Jatinangor (Sumedang) } & \multicolumn{2}{|c|}{ Indramayu } & \multicolumn{2}{|c|}{ Jatinangor (Sumedang) } \\
\hline & & Value & Notation & Value & Notation & Value & Notation & Value & Notation \\
\hline 1. & IP158-5-1 & 1407.6 & e & 459.84 & & 844.14 & e & 380.46 & aefgh \\
\hline 2. & PP48-3-1 & 605.66 & & 766.26 & & 738.94 & efh & 1036.87 & \\
\hline 3. & SP101-3-1 & 806.98 & & 689.25 & & 671.47 & efh & 454.72 & efgh \\
\hline 4. & SP46-4-1 & 1641.14 & efgh & 903.83 & & 771.43 & efh & 951.08 & \\
\hline 5. & SP73-1-1 & 1331.69 & e & 897.93 & & 820.26 & ef & 553.80 & efh \\
\hline 6. & SP73-3-1 & 1613.22 & fgh & 1342.61 & & 696.41 & efh & 835.03 & $\mathrm{~h}$ \\
\hline 7. & SP87-10-1 & 854.58 & & 477.44 & & 1349.71 & & 681.76 & aefh \\
\hline 8. & SP87-1-1 & 1830.16 & fgh & 1360.74 & & 796.30 & ef & 850.29 & \\
\hline 9. & SP87-15-1 & 743.30 & & 671.97 & & 1169.97 & & 436.21 & aefh \\
\hline 10. & SP87-24-1 & 1058.22 & & 532.53 & & 424.82 & befgh & 530.74 & efgh \\
\hline 11. & SP87-25-1 & 799.06 & & 526.69 & & 1036.18 & & 716.03 & efgh \\
\hline 12. & SP87-26-1 & 1277.26 & e & 731.63 & & 1362.09 & & 668.29 & efgh \\
\hline 13. & SP87-27-1 & 2450.85 & abcdefh & 517.59 & & 956.95 & & 870.68 & \\
\hline 14. & SP87-30-1 & 1144.69 & e & 502.08 & & 1025.56 & & 526.08 & efgh \\
\hline 15. & SP87-4-1 & 1735.74 & e & 372.67 & & 1162.81 & & 518.44 & efgh \\
\hline 16. & PTB-33 (a) & 2013.40 & & 1876.21 & & 360.75 & & 451.66 & \\
\hline 17. & IR-42 (b) & 1922.21 & & 1973.21 & & 444.66 & & 319.66 & \\
\hline 18. & Kebo (c) & 2239.54 & & 2133.54 & & 371.99 & & 349.99 & \\
\hline 19. & Pandanwangi (d) & 1944.87 & & 2004.21 & & 248.32 & & 338.99 & \\
\hline 20. & IR-64 (e) & 1071.87 & & 1482.54 & & 865.99 & & 798.32 & \\
\hline 21. & Sintanur (f) & 1432.87 & & 1415.87 & & 824.99 & & 803.32 & \\
\hline 22. & Inpari-13 (g) & 1424.21 & & 1648.87 & & 587.99 & & 551.32 & \\
\hline 23. & Ciherang (h) & 1485.87 & & 1542.54 & & 785.32 & & 843.66 & \\
\hline
\end{tabular}

Remarks: LSI (Least Significant Increase) value for number of productive tillers $=0.647569$; panicle length $=0.275346 ;$ Alphabet $a, b, c, d, f, g, h$ means that that the tested genotype is significantly different compared to the checks listed as follow: $a=$ PTB-33, b = IR-42, $c=$ Kebo, $d$ $=$ Pandanwangi, $e=I R-64, f=$ Sintanur, $g=$ Inpari, $h=$ Ciherang according to $L S I$ at $5 \%$. 
number of empty grains than that of five checks (PTB-33, IR-64, Sintanur, Inpari-13, and Ciherang) in the Jatinangor (Table 3). The number of grains per unit area determined the yield of rice. However, the number of spikelets per unit area is also a major determinant of yield on cereal crops without environmental stress factors (Fischer, 1983; Takeda, 1984; Kropff et al., 1994).

SP73-3-1 (Fig. 1a) becomes the genotype with optimal panicle length, which is expected to produce the optimal number of grains. However, the number of filled grains of this genotype did not exceed that of the checks, resulting in higher number of empty grains exceeding that of the checks. These conditions happened in both planting locations, illustrating the existence of other factors that cause the grains to be not fully filled.

During the rice ripening period, temperature becomes a major factor that influences the duration of grain filling process (Yoshida and Parao, 1977). Matsui et al. (1997) mentioned that rice plants exposed to high temperatures would promote higher spikelet sterility. High temperatures above $300 \mathrm{C}$ will induce sterility in the spikelet, disrupt pollination, and reduce yield. The average temperature in Jatinangor was below $30^{\circ} \mathrm{C}$, but the average temperature in Indramayu was above $30^{\circ} \mathrm{C}$. However, in fact, the number of filled grains in Indramayu was higher than in Jatinangor . It seems that the genotypes tested are more suitable for warm temperature.

The number of grains can be improved by increasing the number of panicles. Modern rice varieties with high yield have a higher number of grains than previous varieties, but there are limits in increasing the number of panicles. Additional tillers that continue to grow can become unproductive so that they only develop more in the vegetative phase, and when producing grains, they are unable to develop filled grains (Khush, 1995). This refer- ence supports that in this experiment, there was no maximal development during vegetative phase, so that the rice grains could not be filled despite the high potential of panicle length. Increasing the number of panicles, panicle sizes, and both can increase the rice yield (sink size). An increase in just one of these characters will not give significant improvement of yield (Ying et al., 1998).

Increased sink size must be accompanied by an improvement in source size. During the filling period of the rice grain, the photoperiod in the planting locations decreased and rainfall increased. However, due to this condition, grain filling process was not supported by optimum photosynthesis process, so that the filling of grains as well as the grains maturation took longer than usual. In short, the generative phase was not optimum, thereby affecting the harvesting time in Jatinangor . Based on the LSI presented in Table 3, there were nine genotypes performing higher number of filled grains than that of the checks in Indramayu, while in Jatinangor, there were no genotypes

Weight of 1000 grains and total grain weight

The weight of 1000 grains weight was observed at $14 \%$ water content. In addition, the estimation of the weight of 1000 grains was carried out through calculations based on the guideline from International Rice Research Institute (IRRI, 2009). The contrast data were found at the two planting locations (Table 4). In Indramayu, there was one genotype showing a greater value compared to seven checks, namely SP87-15-1, and in Jatinangor, there was one genotype, namely SP73-1-1, which was better than four checks. The genotypes of SP73-3-1 (Fig. 1b) and SP87-1-1 (Fig. 1b) tended to be better than several checks at the two planting locations on the total grains weight.

SP87-15-1 was the best genotype among other genotypes on the weight of 1000 grains in Indra- 
Table 4. LSI test for the weight of 1000 grains and total grain weight in Indramayu dan (Jatinangor) Sumedang

\begin{tabular}{|c|c|c|c|c|c|c|c|c|c|}
\hline \multirow{3}{*}{ No. } & \multirow{3}{*}{ Genotype } & \multicolumn{4}{|c|}{ Number of filled grains } & \multicolumn{4}{|c|}{ Number of empty grains } \\
\hline & & \multicolumn{2}{|c|}{ Indramayu } & \multicolumn{2}{|c|}{ Jatinangor (Sumedang) } & \multicolumn{2}{|c|}{ Indramayu } & \multicolumn{2}{|c|}{ Jatinangor (Sumedang) } \\
\hline & & Value & Notation & Value & Notation & Value & Notation & Value & Notation \\
\hline 1. & IP158-5-1 & 30.14 & efgh & 24.42 & & 37.69 & efgh & 9.94 & \\
\hline 2. & PP48-3-1 & 28.34 & efgh & 23.29 & & 14.32 & & 14.69 & \\
\hline 3. & SP101-3-1 & 29.72 & efgh & 28.47 & efh & 20.34 & & 16.75 & \\
\hline 4. & SP46-4-1 & 28.36 & efgh & 21.69 & & 73.65 & abcdefgh & 19.66 & \\
\hline 5. & SP73-1-1 & 32.69 & efgh & 30.78 & efgh & 35.96 & efgh & 24.62 & $\mathrm{~h}$ \\
\hline 6. & SP73-3-1 & 26.63 & fgh & 26.99 & eh & 32.07 & eg & 33.26 & efh \\
\hline 7. & SP87-10-1 & 27.69 & fgh & 26.42 & eh & 20.32 & & 11.52 & \\
\hline 8. & SP87-1-1 & 30.18 & efgh & 28.56 & egh & 42.92 & efgh & 33.93 & efh \\
\hline 9. & SP87-15-1 & 35.37 & abcefgh & 22.81 & & 20.36 & & 14.75 & \\
\hline 10. & SP87-24-1 & 30.01 & efgh & 26.02 & eh & 25.58 & & 12.44 & \\
\hline 11. & SP87-25-1 & 29.78 & efgh & 27.01 & eh & 20.78 & & 12.68 & \\
\hline 12. & SP87-26-1 & 29.63 & efgh & 23.68 & & 32.97 & efg & 15.38 & \\
\hline 13. & SP87-27-1 & 30.16 & efgh & 24.43 & & 68.45 & abcdefgh & 11.98 & \\
\hline 14. & SP87-30-1 & 28.75 & efgh & 26.75 & eh & 27.35 & e & 12.26 & \\
\hline 15. & SP87-4-1 & 30.75 & efgh & 23.52 & & 40.55 & efgh & 8.83 & \\
\hline 16. & PTB-33 (a) & 35.11 & & 34.74 & & 60.61 & & 64.75 & \\
\hline 17. & IR-42 (b) & 32.94 & & 34.22 & & 64.75 & & 66.27 & \\
\hline 18. & Kebo (c) & 34.37 & & 36.73 & & 66.27 & & 50.96 & \\
\hline 19. & Pandanwangi (d) & 36.45 & & 36.36 & & 50.96 & & 60.29 & \\
\hline 20. & IR-64 (e) & 27.93 & & 25.14 & & 60.29 & & 67.28 & \\
\hline 21. & Sintanur (f) & 25.09 & & 27.42 & & 67.28 & & 56.50 & \\
\hline 22. & Inpari-13 (g) & 20.00 & & 28.93 & & 56.50 & & 58.22 & \\
\hline 23. & Ciherang (h) & 25.79 & & 25.69 & & 58.22 & & 26.31 & \\
\hline
\end{tabular}

Remarks: LSI (Least Significant Increase) value for number of productive tillers $=0.647569$; panicle length $=0.275346 ;$ Alphabet $a, b, c, d, f, g, h$ means that that the tested genotype is significantly different compared to the checks listed as follow: $a=P T B-33, b=I R-42, c=$ Kebo, $d$ $=$ Pandanwangi, $e=I R-64, f=$ Sintanur, $g=$ Inpari, $h=$ Ciherang according to $L S I$ at $5 \%$.

mayu because this genotype was better than all 1-1 was only better than cv. Ciherang. Genotypes checks except Pandanwangi. In Jatinangor, there of SP73-3-1 and SP87-1-1 tended to be better than were only eight genotypes that were better than a several checks at the two planting sites (Table 3). few checks. The genotype of SP73-1-1 was the best Grain size is an important quality trait in rice genotype with higher weight of 1000 grains than plants (Unnevehr et al., 1992; Juliano et al., 1993) that of the four checks (IR-64, Sintanur, Inpari-13 and the major determinant of grain weight. The and Ciherang). Based on LSI test, there were two main components of grain size were number of genotypes that were better than all checks on the panicles per plant, number of grains per panicle, total grain weight at Indramayu, namely SP46-4-1 and grain weight. At present, the weight of 1000 and SP87-27-1. Jatinangor planting location showed grains in commercial varieties ranges between 25unacceptable performance for the total grain 35g (Zhang et al., 2012). Genotypes of SP73-1-1, weight. No genotypes were better than checks. Two SP101-3-1, SP87-10-1, SP87-30-1, SP87-24-1, SP87genotypes were better than IR-64, Sintanur, Ci- 25-1, SP73-3-1, and SP87-1-1 had higher weight of herang, namely the SP-73-3-1 and SP-87-1-1. SP73- 1000 grains than some checks in both locations 
(Table 3). SP46-4-1 and SP87-27-1 were superior in total grain weight as seen in Table 3. Grain size is a trait inherited quantitatively from parents (McKenzie and Rutger, 1983). It indicates that the weight of 1000 grains and total grain weight traits have been inherited in these promising lines. The amount of grain production per unit area of land is the main determinant of yield on cereal crops that grow in high-yielding areas without stress factors (Takeda, 1984). One assessment of yield is the total grain weight. The total grain weight is influenced by the yield components and other environmental factors. One environmental factor that affects total grain weight is temperature. Baker et al. (1992) reported that an increase in the maximum temperature of day or night minimum of $28 / 21$ to $34 / 27^{\circ} \mathrm{C}$ reduced the rice yield by $7-8 \%$. In two planting locations, there was no increase in the maximum temperature of the day or the minimum night, which reached $6^{\circ} \mathrm{C}$. In general, changes in global climate conditions can result in an increase in air temperatures of $1.4-5.8^{\circ} \mathrm{C}$ (IPCC, 2001), and according to Peng et al. (2004), there was an increase in average annual minimum and maximum temperatures, which was $0.35^{\circ} \mathrm{C}$ and $1.13^{\circ} \mathrm{C}$, respectively, at IRRI Manila, Philippines. Every temperature increases by $1^{\circ} \mathrm{C}$ of the minimum temperature in the planting season, yield of rice plants decrease by $10 \%$. This statement was conveyed by Peng et al. (2004) who conducted the experiment. According to this study, there was an increase in temperature at both planting locations up to $1^{\circ} \mathrm{C}$. It can be predicted that the total grain weight in the high yielding genotype will be high if the minimum temperature at the planting site is normal. Plant breeders need to increase grain weight per plant by improving the yield component traits (Akinwale et al., 2011). Genetic improvement of rice trait can be focused on the yield component traits that will affect the grain weight and the weight of1000 grains. Genotypes showing superior traits of the weight of 1000 grains and total grain weight can be recommended for further development or to be released as new rice variety.

Contribution of environment factors to the variation of plant traits

The contribution of environmental factors to variations of genotypes' traits grown in Indramayu and Jatinangor can be determined through principal component analysis (PCA). There are two main factors or components (PCs) involved, each factor representing the variables analyzed (Table 5). The eigen value was sorted from the largest to the smallest value, in which the eigenvalue value $<1$ was not used in calculating the number of factors formed (Jolliffe, 2002). Eigenvalue also shows the relative importance of each factor to estimate the variability of the observed variables (Soemartini, 2008). Based on Table 6, only one factor was formed, and the eigenvalue value has a value of more than 1 . Factor 1 (PC1) has an eigenvalue value of 1.808 . The eigenvalue means that this factor can explain 1.808 or $90.410 \%$ of the total.

Table 5. Eigenvalue and variability in the environmental factors

\begin{tabular}{llll}
\hline PC & Eigenvalue & Variability \% & \% Cumulative \\
\hline 1 & 1.808 & 90.410 & 90.410 \\
2 & 0.192 & 9.590 & 100.000 \\
\hline
\end{tabular}

Table 6. Matrix vector value for environmental factors

\begin{tabular}{lll}
\hline Variables & PC1 & PC2 \\
\hline Latitude (LT) & -0.710 & 0.122 \\
Longitude (LG) & -0.253 & 0.080 \\
Height of place/altitude (HG) & 1.054 & -1.586 \\
Maximum temperature (TMAX) & -0.553 & 0.114 \\
Minimum temperature (TMIN) & -0.577 & 0.120 \\
Average temperature (TAVG) & -0.564 & 0.116 \\
Rain fall (RN) & 0.289 & -0.473 \\
Relative humidity (RH) & -0.372 & 0.056 \\
Photoperiod (SUN) & -0.269 & 0.132 \\
Maximum wind speed (MAXWD) & -0.647 & 0.125 \\
Average air pressure (AVGUST) & -0.653 & 0.128 \\
Average wind speed (AVGWD) & -0.661 & 0.126 \\
\hline
\end{tabular}

Remarks: Bolded notation is the variable affecting the variation of genotypes' traits with discriminant value $>0.5$ (Jolliffe, 2002). 


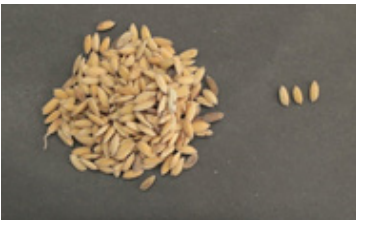

Figure 1a. Grains of SP-73-3-1-2

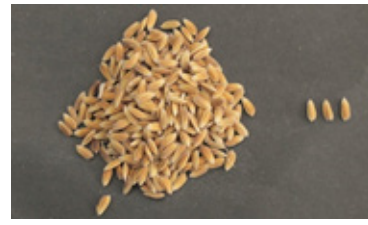

Figure 1b. Grains of SP-87-1-1-7
The height of the location or altitude (above sea level) contributes to variations in the planting location with a variable value greater than 0.5 (Table 6). Based on Table 6, there were two factors (PC) formed. However, the optimal factor to reduce the observed variables is found in PC1 because, in PC1, it can already be seen what variables contribute greatly to the variations that arise at the planting locations. Determination of the variables that contribute was done by looking at the value of each variable in PC1. Variables with a value of more than 0.5 have a large contribution to the variation at the planting location.

Altitude had a greater effect to other environmental conditions. Environmental factors that could be significantly different due to the altitude were temperature and humidity. The rice planting environment is mostly in areas with temperature close to the optimum temperature for rice plant growth at $28 / 22^{\circ} \mathrm{C}$ (Baker et al., 1992). Based on the climatological data, the average temperature in Indramayu during the study was around $32^{\circ} \mathrm{C}$, with maximum and minimum temperatures of $35^{\circ} \mathrm{C}$ and $30^{\circ} \mathrm{C}$, respectively, while the average temperature in Jatinangor was around $28.3^{\circ} \mathrm{C}$, with maximum and minimum temperatures of $3^{\circ} \mathrm{C}$ and $24^{\circ} \mathrm{C}$, respectively. According to Satake and Yoshida (1978), rice plants will be more sensitive to high temperatures and will experience interference at temperatures above $33^{\circ} \mathrm{C}$. Disturbances that occur can directly affect rice yield because they occur during the reproductive process of the reproductive organs. Drought that hit rice plants in vegetative phase can reduce total number of grains (Hariyono, 2014)
The average humidity in Indramayu during the study ranged from $69 \%$ to the highest of $71 \%$, while in Jatinangor, the average humidity was $16 \%$ higher than the average humidity in Indramayu, with the highest humidity of $87 \%$. Humidity of the planting environment will affect the spikelet fertility. The higher percentage of air humidity will decrease fertility of spikelets (Nishiyama et al., 1981, Matsui et al., 1997). Sterility during flowering of rice plants can be induced by high temperature at day and night temperatures of $35^{\circ} \mathrm{C}$ and $30^{\circ} \mathrm{C}$, respectively, together with high humidity of $90 \%$ (Abeysiriwardena et al., 2002). The average rainfall in Indramayu was lower than int Jatinangor. During growing phase, the average rainfall in Indramayu was $105.56 \mathrm{~mm}$, while in Jatinangor, it ranged at an average of $359.88 \mathrm{~mm}$. The high amount of rainfall occurred at the end of the growing season in both locations with successive increase in both Indramayu and Jatinangor reaching $170.51 \mathrm{~mm}$ and $652.48 \mathrm{~mm}$, respectively. In contrast to rainfall, the average photoperiod in Indramayu was longer than in Jatinangor, which was longer by 26.507 hours. The longest photoperiod occurred with 118.66 hours in Indramayu when entering the final stage of maturity and 123.30 hours in Jatinangor in the vegetative growth phase of planting.

Other important environmental factors affecting the rice growth and development is wind. The wind mostly helps in the occurrence of pollination. Wind speed can reduce humidity on anther and spikelet. Matsui et al. (1997) reported that the effect of wind disturbances on pollination might depend on the position of the anther. High wind speed could eliminate a number of pollen and disrupt the self-pollination. Spikelets that develop at high temperatures will be more sensitive to the presence of wind. During planting, the wind speed in Indramayu planting location was at an average of 8.35 miles per hour ( $\mathrm{mph}$ ), whereas in Jatinangor, it was $3.4 \mathrm{mph}$. The highest wind speed occurred 
in Indramayu was $10.1 \mathrm{mph}$ in the third month, while in Jatinangor, it was only $3.6 \mathrm{mph}$ in the second and third months.

\section{CONCLUSION}

The genotypes of SP73-3-1 and SP87-1-1 had better yield and yield components than those of the checks in two different planting locations, which were Indramayu (9asl) and Jatinangor (753asl). SP87-1-1 had a higher number of filled grains than the check in Indramayu. The planting location has a contrasting altitude. The height of the place (altitude) is an environmental factor that have largest contribution to the variation of the rice plant traits. The genotypes of SP73-3-1 and SP87-1-1 were able to demonstrate their superiority by being able to adapt and show better yield and yield components than checks at two planting sites. The genotypes of SP73-3-1 and SP87-1-1 are recommended to be grown in low and medium agro-climatic environments.

\section{ACKNOWLEDGEMENTS}

The authors would like to thank to Ministry of Research, Technology and Higher Education for supporting the research through Competitive Research Grant for Higher Education (PUPT) 2017 awarded to NC. Thank you also goes to 'Gene Designer' research team.

\section{REFERENCES}

Abebrese, S.O., Yeboah, A., Dogbe W., Dartey, P.K.A., Akromah, R., Gracen, V.E., Offel, S.K., \& Danquah, E.Y. (2019). Evaluation of yield, reaction to diseases, and grain physical attributes of some introduces rice hybrid in Ghana. International Journal of Agronomy. Vol. 2019. Article ID 3926765, 8 pages. https://doi. org/10.1155/2019/3926765.

Abeysiriwardena, D.S.Z., Ohba, K., \& Maruyama, A. (2002). Influence of temperature and relative humidity on grain sterility in rice. J. Natn. Sci. Found. Sri Lanka. 30, pp. 33-41.

Akinwale, M.G., Gregorio, G., Nwilene, F., Akinyele, B. O., Ogunbayo, S. A., \& Odiyi, A. C. (2011). Heritability and correlation coefficient analysis for yield and its components in rice (Oryza sativa L.). African Journal of Plant Science Vol. 5 (3), pp. 207-212.
Ando, T., Toshio, Y., Takehiko, S., Xiu, F.M., Ayahiko, S., Yoshinobu, T., Shao, Y.L., \& Masahiro, Y. (2008). Genetic dissection and pyramiding of quantitative traits for panicle architecture by using chromosomal segment substitution lines in rice. Theor Appl. Genet. 116:881890

Annicchiarico, P. (2002). Defining adaptation strategies and yieldstability targets in breeding programs. In M.S. Kang (ed.), Quantitative Genetics, Genomics and Plant Breeding, pp. 365-383. CABI Publishing, Wallingford, Oxon, UK.

Badan Pusat Statistik. (2015). Produksi Padi, Jagung, dan Kedelai. Berita Resmi Statistik Rilis 1 Juli 2015. Dalam https://www.bps. go.id/Brs/view/id/1157 Diakses 20 November 2016.

Baker, J.T., Allen, J.L.H., \& Boote, K.J. (1992). Temperature effectson rice at elevated co concentration. J. Exp. Bot. 43, 959-964.

Barma, P., Sarkar, S., Sarkar, R.K., Moktan, M.W., Ali, S., Rahaman, F.H., \& Burman, R.R. (2018). An on-farm trial to evaluate the performance of the improved rice varieties in Darjeeling district of west Bengal. Journal of Entomology and Zoology Studies. 6(6): 78-81.

Dianawati, M., \& Noviana, I. (2015). Yield potential of irrigated rice lines at low land area in Distrcit of Ciamis, West Java (In Bahasa Indonesia). Agrin 19(2):97-104.

Fehr, W. R. (1987). Principles of Cultivar Development. Theory and Technique.Vol.1. Macmillan Publishing Company. NY.

Fischer, R.A. (1983). Wheat. In: Smith, W.H., Banta, S.J. (Eds.). Potential Productivity of Field Crops Under Different Environments. International Rice Research Institute, Los Banos, Philippines, pp. 129-154.

Ganefianti, D.W., Suryati, D., \& Hasannudin. (2009). Analisis stabilitas hasil enam genotipe cabai menggunakan metode additive main effect multiplicative interaction (AMMI). Akta Agrosia 12:147-154.

Gaspersz, V. (2006). Experimental Design Methods (In Bahasa Indonesia). CV. ARMICO, Bandung.

Gravois, K.A., \& Helms, R.S. (1992). Path analysis of rice yield and yield components as mected by seeding rate. Agronomy Journal. Vol. 84, January-February 1992

Hariyono. (2014). Keragaan Vegetatif dan Generatif Beberapa Varietas Tanaman Padi (Oryza sativa L.) terhadap Cekaman Kekeringan pada Fase Pertumbuhan yang Berbeda. Planta Tropika Journal of Agro Science Vol 2 No 1 / Februari 2014.

IRRI (International Rice Research Institute). (2009). Standard Procedure For Determining Yield Components. Dalam Harvest. Diakses dari https://sites.google.com/a/irri.org/ oryza2000/ calibration-and-validation/experimental-data-collection-andanalysis/standard-procedure-for-determining-yield-components-at-harvest. Diakses 12 Juli 2017.

IPCC. (2001). In: Houghton, J.T., Ding, Y., Griggs, D.J., Noguer, M., Van der Linden, P.J., Da, X., Maskell, K., Johnson, C.A.(Eds.), Climate Change 2001: Scientific Basis. Cambridge University Press, New York, USA

Jolliffe, I.T. (2002). Principal Component Analysis (2nd ed.). SpingerVerlag New York, Inc.

Juliano B.O., \& Villareal, C.P. (1993). Grain quality evaluation of world rices. International Rice Research Institute, Manila.

Kementerian Pertanian. (2015a). Atlas peta pengembangan kawasan padi abupaten Indramayu Provinsi Jawa Barat. Diakses 
dari http://www1.pertanian.go.id/sikp/files/pjku50/CETAK_INDRAMAYU_FINAL.pdf

Kementerian Pertanian. (2015b). Atlas peta pengembangan kawasan padi kabupaten Sumedang Provinsi Jawa Barat. Diakses dari http://www1.pertanian.go.id/sikp/files/pjku50/ CETAK_SUMEDANG_FINAL.pdf

Khush, G.S., \& Brar, D.S. (2002). Biotechnology for rice breeding: progress and impact. In: Sustainable rice production for food security. Proceedings of the 20th Session of the International Rice Commission (23-26 July, 2002). Bangkok, Thailand.

Khush, G.S. (1995). Breaking the Yield Frontier of Rice. Geojournal 35.3/1995. Kluwer Academic Publishers

Kropff, M. J., Cassman, K.G., Peng, S., Matthews, R.B., \& Setter, T.L. (1994). Quantitative understanding of yield potential. In: Cassman, K.G. (Ed.). Breaking the Yield Barrier. International Rice Research Institute, Los Banos, Philippines, pp. 21-38.

Mackill, D.J. \& Kush, G.S. (2018). IR64: a high-quality and highyielding mega variety. Rice 11:18 https://doi.org/10.1186/ s12284-018-0208-3

Matsui, T., Kenji, O., \& Takeshi, H. (1997). High temperature-induced spikelet sterility of japonica rice at flowering in relation to air temperature, humidity and wind velocity conditions. Japan Journal of Crop Science. 66 (3): 449-455.

McKenzie, K.S., \& Rutger, J.N. (1983) Genetic analysis of amylose content, alkali spreading score, and grain dimensions in rice. Crop Sci 23 pp. 306-313

Mohamed, A.H., Amin, S. \& Hanna. (1965). Inheritance of Quantitative Characters in Rice: Inheritance of Panicle Length. Canadian Journal of Genetics and Cytology, 1965, Vol. 7, No. 3: pp. 406-417

Nishiyama, I., \& Satake, T. (1981). High temperature damage in the rice plant. Jpn. J. Trop. Agric. 26, 19-25.

Pearson, K. (1901). On lines and planes of closest fit to systems of points in space. Philosophical Magazine. 2 (11): 559-572. doi:10.1080/14786440109462720.

Peng, S., Huang, J., Sheehy, J.E., Laza, R.C., Visperas, R.M., Zhong, X., Centeno, G.S., Khush, G.S. \& Cassman, K.G. (2004). Rice yields decline with higher night temperature from global warming. Proc. Natl. Acad. Sci. USA 101: 9971-9975.

Petersen, R.G. (1994). Agriculture Field Experiments. Marcel Dekker, Inc, New York.

Satake, T., \& Yoshida, S. (1978). High temperature-induced sterility in indica rice at flowering. Jpn. J. Crop Sci. 47: 6-17.

Sharma, J.R. (2006). Statistical and Biometrical Techniques in Plant Breeding. New Age International Publishers, New Delhi, India.

Sheehy, J.E., Dionora, M.J.A., \& Mitchell, P.L. (2001). Spikelet numbers, sink size and potential yield in rice. Field Crops Research 71: 77-85

Smith, M.R., Rao, I.M., \& Merchant, A. (2018). Source-sink relationships in crop plants and their influence on yield development and nutritional quality. Front. Plant Sci. 9:1889.

Soemartini. (2008). Principal Component Analysis (PCA) sebagai salah satu metode untuk mengatasi masalah multikolinearitas. Jurusan Matematika. Fakultas MIPA UNPAD.

Syarif, A.A., \& Zen, S. (2012). Adaptation and yield stability of eight local varieties of paddy rice (In Bahasa Indonesia). Buletin Plasma Nutfah 18(2):62-69.
Syuriani, E., E., Wentasari, R., \& Kartahadimaja, J. (2013). Uji daya hasil sepuluh galur baru tanaman padi (Oryza sativa L.) rakitan Politeknik Negeri Lampung. Jurnal Penelitian Pertanian Terapan Vol. 13 (3): 174-179. ISSN 1410-5020.

Takeda, T. (1984). Physiological and ecological characteristics of high yielding varieties of lowland rice. In: Proceedings International Crop Science Symposium, Fukuoka, Japan 1984

Unnevehr L.J., Duff, B., \& Juliano, B.O. (1992). Consumer demand for rice grain quality. International Rice Research Institute, Manila, and International Development Research Center, Ottawa.

Uzzaman, T., Sikder, R.K., Asif, M.l., Mehraj, H., \& Jamal Uddin, A.F.M. (2015) Growth and yield trial of sixteen under system of rice intensification. Sci.Agri. 11 (2): 81-89.

Xiong Z. M. (1992). Research outline on rice genetics in China. In: Xiong ZM, Cai HF (eds). Rice in China. Chinese Agricultural Science Press, Beijing, pp 40- 57

Xue, W., Xing, Y., Weng, X., Zhao, Y., Tang, W., Wang, L., Zhou, H., Yu, S., Xu, C., Li, X., \& Zhang, Q. (2008). Natural variation in Ghd7 is an important regulator of heading date and yield potential in rice. Nature Genetics, 40(6), 761-767.

Yan, J.Q., Zhu, J., Benmoussa, C.X., He, M., \& Wu, P. (1998). Quantitative trait loci analysis for the developmental behavior of tiller number in rice (Oryza sativa L.) Theor Appl Genet.97 : 267-274.

Ying, J., Peng, S., He, Q., Yang, H., Yang, C., Visperas, R. M., \& Cassman, K. G. (1998). Comparison of high-yield rice in tropical and subtropical environments. Field Crops Research, 57(1), 71-84.

Yoshida, S., \& Parao, F.T. (1977). Climatic influence on yield and yield components of lowland rice in the tropics. In: Climate and Rice, International Rice Research Institute, Los Banos, The Philippines, pp 471-494

Zhang, X., Wang, J., Huang, J., Lan, H., Wang, C., Yin, C., Wua, Y., Tanga, H., Qian, Q., Li, J., \& Zhang, H. (2012). Rare allele of OsPPKL1 associated with grain length causes extra-large grain and a significant yield increase in rice. Proceedings of the National Academy of Sciences, 109(52): 21534-21539. 